\title{
Significado de Cristo Médico en san Agustín
}

\author{
Prof. Dr. Ramón Sala GonzÁlez \\ Estudio Teológico Agustiniano, Valladolid.
}

Recibido: 17 de julio 2021

Aceptado: 11 de octubre 2021

Resumen: Los Sinópticos atribuyen a Cristo el título de Médico para describir su actividad sanadora (cf. Mc 2,17 par; Lc 4,23). También san Agustín lo usa a menudo en sus escritos, sobre todo, en su predicación. El artículo presenta la lectura agustiniana de esta imagen en continuidad con la tradición patrística anterior y después de repasar algunos de sus presupuestos culturales y religiosos. El "Médico humilde" de san Agustín es un poderoso símbolo, que comunica la única mediación salvífica de Cristo con un lenguaje fácilmente reconocible en nuestros días.

Palabras Clave: San Agustín, Cristo Médico, títulos cristológicos, soteriología patrística.

Abstract: The Synoptics attribute the title of Doctor to Christ in order to describe his healing activity (cf. Mk 2:17; Lk 4:23). It is often use by St. Augustine's works as well, primarily in his preaching. The article presents the Augustinian reading on this image, following the previous Patristic Tradition and after retrieving some of its cultural and religious background. St. Augustine's "Medicus humilis" is a powerful symbol that communicates the unique saving Mediation of Christ in terms easily acknowledged today.

Key Words: Saint Augustine, Christus Medicus, Christological Titles, Patristic Soteriology. 
Aproximadamente tres de cada cuatro relatos evangélicos de milagros se refieren directamente a curaciones físicas o mentales obradas por Jesús. Desde sus orígenes las comunidades apostólicas comprendieron esos gestos sanadores como signos de la presencia de la gracia salvadora de Dios. Tanto en los escritos del NT, como en la literatura cristiana antigua nos encontramos abundantemente con la imagen de Cristo Médico. En los ss. II y III los Padres de la Iglesia se sirvieron de ella frente a las divinidades mitológicas de la salud (en concreto, Asclepio) y, desde el s. IV, contra los cultos mistéricos. Este estudio se centra en el tratamiento que san Agustín da a este motivo.

Sin proceder de un modo estrictamente diacrónico, la exposición consta de cuatro secciones y la conclusión. Parte de la religiosidad grecolatina (pagana y maniquea), para repasar después las fuentes patrísticas (pre y postnicenas). El objetivo es poner de relieve la interpretación agustiniana de Cristo Médico y su valor soteriológico.

\section{EN BUSCA DE LA SALUD}

\subsection{ASCLEPIO, DIOS DE LA MEDICINA}

El proceso asimilador de la religión griega por los romanos comenzó a llevarse a cabo hacia mediados del s. IV a. C., cuando Roma entra en contacto con las polis del sur de Italia -la antigua Magna Grecia-, acogiendo en su seno a sus divinidades, además de muchas de sus costumbres. En la Eneida de Virgilio, poema encomendado por el emperador Augusto para conmemorar la fundación del Imperio, los orígenes del estado romano y del propio emperador se hacen remontar a los dioses olímpicos griegos $^{1}$. Además de las principales divinidades masculinas y femeninas del panteón griego, la mitología latina asimiló también otras muchas. Entre ellas el dios de la medicina, Asclepio, bajo el nombre de Esculapio (Aesculapius).

El culto a Esculapio fue introducido en Roma en el año 291 a. C. con ocasión de una gran peste que asoló la urbe durante un largo período.

${ }^{1}$ Siendo niño san Agustín adquirió afición por la lectura practicando con esta obra clásica latina como evoca en conf. 1,13,20-22 (cf. s. 81,9;241,5). Cf. P. COURCELLE, Lecteurs païens et lecteurs chrétiens de l'Enéide. 1. Les témoinages littéraires, Paris 1984. 
Consultados los oráculos sibilinos, para hacer cesar la enfermedad, se determinó enviar una embajada a Epidauro (Peloponeso) donde se encontraba el templo más famoso de la divinidad. Allí "el que sana dulcemente"

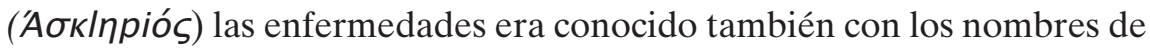
$\Sigma \omega т \eta ́ \rho$ y Kó $\theta \alpha \rho \sigma ı \varsigma$. Cuenta la leyenda (Tito Livio, Ovidio) que Asclepio, tras escuchar los ruegos desesperados de los emisarios, se avino a viajar a la capital imperial metamorfoseado en una gigantesca serpiente. Al llegar la nave al puerto de Ostia, el animal se zambulló en las aguas del Tiber dirigiéndose a nado hasta Roma. La isla Tiberina, donde fijó su residencia, fue consagrada a Esculapio, edificándose en ella un santuario en el que se practicaban curaciones según los ritos de Epidauro.

Según la mitología griega, el dios Asclepio fue engendrado por Apolo, a quien también se atribuía la facultad de curar, y la heroína inmortal Carónide, hija del rey de Tesalia. Durante su embarazo, Carónide se enamoró de Isquis y pagó su infidelidad asaeteada por Artemisa, hermana gemela del dios de la belleza masculina. En el momento en que su cuerpo era colocado sobre la pira, Apolo arrancó de su seno al niño, naciendo de este modo Asclepio. El bebé fue confiado por su padre al centauro Quirón, quien le instruyó en los conocimientos y técnicas de la medicina. Pronto, el joven adquirió una gran destreza en las artes curativas, llegando incluso a descubrir el modo de resucitar a los muertos. Alertado por Hades, rey de los infiernos, y temiendo que Asclepio con sus poderes desbaratase el orden de la naturaleza, Zeus lo fulminó con un rayo. Para vengar a su hijo -continúa el mito-, Apolo destruyó a los cíclopes, dioses encargados de forjar los rayos de Zeus. Tras su muerte, Asclepio fue trasformado en una constelación estelar. Los relatos mitológicos refieren también las dotes sanadoras de sus descendientes, en particular de su hija Higía (Salus), que a menudo compartió culto con él².

Asclepio -y también Esculapio, su versión romana, cuyas imágenes lo reproducen exactamente- es representado como un hombre maduro y

${ }^{2}$ La mujer de Asclepio, Epíone, calmaba el dolor; su hija Panacea es la divinidad de los tratamientos curativos; su hijo Telesforo simboliza la convalecencia; y Macaón y Podalirio, dioses protectores de médicos y cirujanos. Higía -de donde procede "higiene"-, personificación del bienestar físico y espiritual, era invocada para prevenir las enfermedades. A ella era dedicada la fiesta de la "Salus Populi Romani", para honorarla como divinidad garante de la salud de los ciudadanos del imperio. 
barbado, cuyo rostro recuerda al propio Zeus y expresa la nobleza de esta figura benefactora de la humanidad. Su atributo principal es una serpiente enroscada en un bastón ("vara de Esculapio"), símbolo de la renovación de la fuerza vital. En torno al culto a Asclepio, se desarrolló en Epidauro una verdadera escuela de medicina y sus sacerdotes (asclepiades) instalaron un gran hospital que gozó de gran fama en el mundo antiguo. El más célebre de los sacerdotes de Epidauro fue Hipócrates, cuya familia, según la leyenda, descendía del mismo dios Asclepio.

En Roma las fiestas en honor a Esculapio comportaban variados ritos con oraciones y sacrificios. Del culto al dios de la salud participaba todo el pueblo, según revelan las fuentes arqueológicas y epigráficas. No sólo era invocado por quienes padecían enfermedades incurables o no podían acceder a las medicinas, sino también por quienes no querían someterse a dolorosas curas -no siempre eficaces- y por personas cultas ${ }^{3}$.

\subsection{El CRisto de los MANiQueos}

De acuerdo con la cosmología del maniqueísmo -corriente religiosa, sincrética y dualista, iniciada por Manes en el s. III- la materia creada procede de un principio del mal opuesto al reino de la luz. Está gobernada por el "Príncipe de las tinieblas", que se introduce en la luz a través de hipóstasis demoníacas. Por su parte, del "Padre de las luces" emanan siempre eones divinos para salvar al mundo de las tinieblas. Uno de ellos es el "Cristo luminoso", que bajó a la tierra en forma humana, para liberar la porción divina de Adán (alma) encerrada en el cuerpo por el pecado.

Al mismo Salvador nuestro, tu Unigénito, de tal modo lo juzgaba salido de aquella masa lucidísima de tu mole para salud nuestra, que no creía de él sino lo que mi vanidad me sugería. Y así juzgaba que una tal naturaleza como la suya no podía nacer de la Virgen María sin mezclarse con la carne, ni veía como podía mezclarse sin mancharse lo que yo imaginaba tal. Y así temía creerle nacido en la carne, por no verme obligado a creerle manchado con la carne (conf. 5,10,20).

${ }^{3}$ Cf. G. D. Hart, Asclepius: The God of Medicine, London 2000. Por ejemplo, el orador Cicerón, admirado por el joven Agustín, le pedía al dios por su mujer Terenzia enferma (citado por A. FrAGALE, "Le divinità della salute:Asclepio/Esculapio ed Igea/Salus" en archeofriuli.it/wp-content/uploads/2016/11/Asclepio-ed-igea.pdf). 
San Agustín simpatizó con la secta maniquea como "oyente" por espacio de unos diez años (373-383), según cuenta él mismo en las Confesiones ${ }^{4}$. Admitiendo que la visión de un convertido nunca puede ser totalmente objetiva, no hay por qué cuestionar la fiabilidad de sus palabras. Ciertamente, el maniqueísmo profesaba una fervorosa piedad hacia Cristo, Poder y Sabiduría de Dios (1Cor 1,24). Le atribuían también el título de "Medicus". Cristo es, ante todo, un salvador", pero se trata de un salvador fantasmal (cf. conf. 3,6,10). La cristología maniquea es doceta. No admitían la encarnación-considerada una contaminación-ni siquiera en el seno de una virgen (cf. c. Faust. 2,1). Su concepción de un Cristo espiritual, apoyada en su particular interpretación de la cristología joánica, incluso le confesaba como "camino, verdad y vida", pero no dejaba de ser un Cristo desencarnado. Es verdad que sus formulaciones, a veces, se asemejan a las de la Iglesia: "creemos que Cristo el salvador vino del cielo para cumplir la voluntad del Padre. Voluntad del Padre que era ésta: liberar nuestras almas de la enemistad, dándole muerte a ella" (c. Fort. 1,17). También hablan del "Iesus patibilis" y de su "mystica passio" como causa de nuestra salvación. Sin embargo, Cristo no es un salvador humano nacido y muerto en la cruz por nuestra redención. Es más bien un enviado celestial para invitar al retorno de las almas a su origen divino. La salvación la ha realizado por su enseñanza ("sciencia rerum"). Su pasión y muerte son sólo metáforas. Cristo crucificado significa la porción de Dios atrapada en la materia. Y ésta es incurable porque pertenece al mal. El Cristo maniqueo está crucificado en todo el mundo y en toda alma, muestra las llagas de la humanidad enferma. La misión salvífica de Cristo consiste en recordarnos nuestro origen y nuestra patria. Según san Agustín, el propio Fausto reconoce la distancia del maniqueísmo de la fe católica: "aunque venere y rinda culto a Cristo... lo hago con otro rito y desde otra fe" (c. Faust. 20,4).

${ }^{4}$ Hay autores que hablan de nueve años. En cualquier caso, el tenor de su adhesión a la secta es un dato interpretable. Parece que san Agustín vivió dos etapas diversas (entusiasmo inicial y decepción progresiva) y no llegó a pertenecer formalmente al grupo de los "electi" de la secta, aunque él dice que frecuentaba también los círculos de "los que llaman elegidos" (conf. 5,10,18).

5 Cf. J. D. BEDUHN, «A Regimen for Salvation: Medical models in Manichaean ascetism»: Semeia 58 (1992) 111-124; J. K. CoYLE, «Healing and the 'Physician' in Manichaeism» in Manichaeism and its Legacy, Boston 2009, pp. 111-115. 
El lenguaje dualista maniqueo empleado para describir la obra de Cristo utiliza una gran profusión de verbos ${ }^{6}$, entre los que sobresale "liberar" por su frecuencia. En efecto, el objetivo es liberar la parte de la sustancia divina que, a consecuencia de la lucha primordial, quedó prisionera de la materia. La soteriología maniquea tiene como fundamento bíblico Flp 2,5-8. Igual que Cristo, el hombre existía inicialmente en la forma de Dios (la partícula divina en él). En Cristo experimentamos también nosotros el destino final de nuestras almas. Para que tenga lugar esa liberación, a semejanza de la de Cristo, se requiere un renacimiento, que consiste en recordar el propio ser original. Por eso, la salvación tiene lugar formalmente a través del conocimiento que Cristo nos ha traído, completado con la enseñanza de Manes, el Paráclito enviado por él (cf. conf. 5,5,8-9).

Los maniqueos proponían una comida ritual para la salvación o liberación de partículas divinas. En este sentido, los electi también eran llamados "médicos". Para ellos el bien y el mal son sustancias materiales. La digestión era el medio medicinal de salvación mediante el cual las almas eran físicamente separadas de la "substancia del mal". Entonces la salvación era el resultado de esa digestión...7.

Si bien es obvio que san Agustín refutará clara y ampliamente tan histriónica soteriología, no se puede negar que la imagen de destierro y cautividad y el deseo de liberación, depurados de sus elementos míticos, penetraron de algún modo en él ${ }^{8}$. Sin embargo, el Salvador nada tiene que ver con el cristo maniqueo y la salvación cristiana es salud de toda la persona. La concepción maniquea de una carne incurable excluida de la salvación, porque es intrínsecamente mala, resulta totalmente extraña a la fe cristiana. En cambio, san Agustín pudo compartir con Pablo y con los maniqueos el sentimiento de lejanía de Dios y de peregrinación hacia la patria celeste.

${ }^{6}$ Algunos de ellos claramente sanadores como "curare", "purgare" o "mundare". Cf. P. DE LuIS, «San Agustín y el maniqueísmo» en OCSA XXX, Madrid 1986, pp. 54-64.

${ }^{7}$ Cf. A. Palliparambil, «De Agone christiano. A Project of Christian Life in contrast with Manichaeism»: Estudio Agustiniano 49 (2014) 441-501; 50 (2015) 5-59.

${ }^{8}$ Cf. J. RIES, «Jésus Sauveur dans le controverse anti-manichéenne de Saint Augustin» en J.van Oort, O. Wermelinger, G. Wurst, eds., Augustine and Manichaeism in the Latin West, Leiden-Boston-Köln 2001, pp. 185-194; J. VAN OORT, «Augustine and Manichaeism: new discoveries, new perspectives»: Verbum et Ecclesia JRG 27 (2006) 709-728. 


\section{UN TÍTULO TRADICIONAL}

\subsection{Patrística prenicena}

La presentación de Cristo como Médico está muy presente en la tradición cristiana primitiva ${ }^{9}$. Ante la enfermedad, el cristianismo proclama a Cristo-Salvador, quien procura la verdadera salud, en contraste con las ofrendas a las divinidades o el recurso a los médicos y curanderos. Ignacio de Antioquía es el primero de los Padres de la Iglesia que llama médico

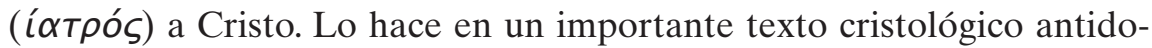
ceta $^{10}$. Contiene una fórmula bimembre antitética que expresa la distinción entre lo humano y lo divino en Cristo, subrayando a la vez la unidad. Encabezadas por ese título soteriológico ("hay un solo Médico"), el texto presenta dos series de afirmaciones paralelas sobre el único Cristo Médico. Primero las relativas a su humanidad (carnal, creado, mortal, nacido de María, pasible) y después a su divinidad (espiritual, increado, vida, nacido de Dios, impasible). Tendrá una gran influencia en la explicitación posterior del dogma cristológico.

El empleo del título "Cristo Médico" va a recibir un fuerte impulso en los siglos II y III. En el contexto de la confrontación con el culto a Asclepio, "el Salvador y Sanador", los Padres apologistas oponen las sanaciones de Cristo a las de la divinidad pagana. San Justino asegura que Cristo "se ha hecho hombre para que participando de nuestras pasiones se convirtiese en su medicina" (Apol. II,12) y que es el único justo "por cuyas llagas son curados los que por Él se acercan al Padre" (Dial. 17,1). Teófilo de Antioquía se pregunta por la identidad del médico que cura y vivifica la "ceguera del alma". Él atribuye el título a Dios, pero afirma que el Logos es el mediador de su acción sanadora (Ad Autolycum 1,7). Hay algunas alusiones en términos semejantes también en Ireneo de Lyon (cf. Adv. Haer. III,5,2).

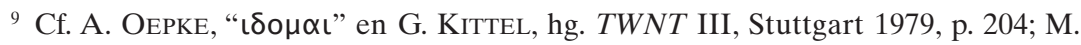
DöRnEMANn, Krankheit und Heilung in der Theologie der frühen Kirchenväter, Tübingen 2003, pp. 58-67; A. -M. VANniER, "L'image du Christ médicin chez les Pères" en V. BoudonMillot - B. Pouderon, ed., Les Pères de l'Église face à la science médicale de leur temps, Paris 2005, pp. 525-553.

${ }^{10}$ IgEf 7,2: "Alerta contra ellos [los docetas] ya que sufren una enfermedad muy difícil de curar. Hay un solo Médico, carnal y espiritual, creado e increado, en la carne hecho Dios, en la muerte vida verdadera, de María y de Dios, primero pasible y luego impasible, Jesucristo nuestro Señor". 
Para Tertuliano las curaciones de Jesús muestran la unidad de los dos testamentos porque habían sido profetizadas ya por Is 53,4 y muestran, además, la realidad de la humanidad de Cristo (cf. Adv. Marc. IV,8,4). Sin embargo, aunque critica con dureza la impiedad de Esculapio (cf. Apolog. 14,20), excepcionalmente Tertuliano evita la figura de Cristo médico en sus escritos. No la menciona frente a los herejes marcionitas porque estos utilizaban la imagen de Lc 5,31 para mostrar que Cristo ha venido a salvar a los paganos, extraños al judaísmo. Tampoco la usa en sus obras rigoristas porque sugiere que el pecador siempre puede recurrir al Médico para ser sanado de sus pecados - Tertuliano admitía una sola penitencia postbautismal-.

En cambio, el apelativo "médico" aplicado a Cristo tuvo una gran difusión entre los Padres alejandrinos. En el precursor de esta escuela, Clemente de Alejandría, la figura de Cristo médico aparece a propósito de la discusión sobre la condición de "prójimo" según la parábola del buen samaritano: "Jesús es el único médico, el que corta totalmente las pasiones de raíz" (Quis dives salvetur? 29). En la primera parte del Pedagogo se encuentra un amplio desarrollo de la imagen del Logos como Pedagogo

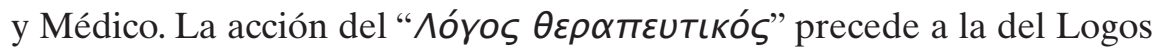
pedagogo, pero ambos se identifican porque "las enfermedades del alma precisan un pedagogo que cure las pasiones" (Paed. I,3,3). En el Protréptico el Salvador es comparado con un buen médico que aplica diversos remedios para curar los cuerpos enfermos (cf. Protr. 8,2) frente al médico "avaro" Asclepio (cf. Protr. 2,22,1-2).

De todos los Padres prenicenos es Orígenes quien ha descrito con más extensión y usado con más frecuencia el título de Médico aplicado a Cristo $^{11}$. Se le puede considerar el autor del primer "tratado de los nombres de Cristo", inserto en el libro I de su Comentario al evangelio de san $J_{u a n^{12}}$. Siguiendo la doctrina estoica, para él las denominaciones (Emívoı $\alpha \iota$ ) describen a la persona de Cristo y son una vía de acceso a su realidad más profunda, aunque nunca pueden agotar su misterio. En su exhaustivo estudio sobre la obra origeniana citada, H. Crouzel clasifica el

${ }^{11}$ La observación es de A. von Harnack (citado por S. Fernández, Cristo Médico según Orígenes. La actividad médica como metáfora de la acción divina (Studia Ephemerides Augustinianum 64), Roma 1999, p. 9).

12 También trata extensamente este tema en De Principiis I,2. 
título de Medicus entre los nombres de Cristo "designados por un título humano"13. Aunque podemos y debemos hablar de Cristo desde diversas perspectivas, plasmadas en los distintos nombres que le aplicamos, Orígenes advierte que "en mi Señor y Salvador Jesús no hay más que una única persona" (In Ioan. I, 28,200). Cristo es médico porque según el NT "no tienen necesidad de médico, sino los enfermos" (Mt 9,12). Él ha venido a curarlos. Quien se acerca a Jesús y se deja sanar por Él, recupera la salud y Cristo "le infunde una maravillosa mansedumbre y equilibrio de carácter, humanidad, bondad y dulzura" (Contra Celso I,27). Orígenes defiende la superioridad de Cristo Médico sobre otros médicos (profetas, ángeles, filósofos) y su actuación en bien de los hombres (curaciones de Jesús). En la polémica con Celso, que rechazaba la idea cristiana de una encarnación divina, Orígenes contrapone a Cristo con Asclepio, el "demonio médico" (Contra Celso III,59).

\subsection{Patrística postnicena}

A partir del s. IV el uso apologético del título "médico" es dirigido por los autores cristianos frente a los cultos mistéricos, sus rituales secretos y especialmente sus promesas de salvación e inmortalidad. En cambio, contra las tesis arrianas, el dogma niceno va a privilegiar los grandes títulos cristológicos del símbolo de fe (Cristo, Señor, Hijo, Unigénito). No obstante, Cristo Médico va a ser retomado por los Padres griegos: está presente en los Capadocios, en san Cirilo de Jerusalén, en Efrén el Sirio y en Evagrio Póntico.

En su Tratado sobre el Espíritu Santo, san Basilio enumera Médico $(\mathrm{Mt} \mathrm{9,12)} \mathrm{junto} \mathrm{a} \mathrm{otros} \mathrm{títulos} \mathrm{no} \mathrm{confesionales} \mathrm{(Pastor,} \mathrm{Rey,} \mathrm{Esposo,} \mathrm{Ca-}$ mino, Puerta, Fuente, Pan, Hacha, Roca) que indican la variedad de actividades de Cristo en favor de los hombres (Sobre el Espíritu Santo 8,18). Llama a Cristo "médico de las almas" y "médico misericordioso". A la voluntad de Basilio se debe la fundación en Cesarea del primer hospital público (370). San Gregorio Nacianceno ve en la encarnación del Logos la

${ }^{13}$ Cf. H. Crouzel, "Le contenu spirituelle des dénominations du Christ selon le livre I du Commentaire sur Jean d'Origène" en Origeniana Secunda (Quaderni de Vetera Christianorum 15), Roma 1980, pp.131-150). Otras clasificaciones lo colocan entre los nombres infralapsarios o los que califican a Cristo en relación con la humanidad (cf. A. GrillmeIER, Cristo en la tradición cristiana, Salamanca 1997, p. 300). 
"medicina" para las enfermedades del mundo (cf. Homilía sobre la Navidad 38,13). Por su parte, justificando el misterio de la cruz, san Gregorio de Nisa argumenta que corresponde al médico -y no al enfermo- prescribir la medicina más efectiva para curar la enfermedad (cf. Gran Catequesis 17,2). Frente a la gnosis valentiniana, que a partir de sus diversos títulos introducían varios cristos, las Catequesis de san Cirilo de Jerusalén explican el significado sanador del nombre propio de Jesús: "recibe este apelativo de la medicina salvadora" (X,4; cf. X,13; XII,8-9). Otro representante de la escuela antioquena, el monje Efrén, aplica a Jesús los apelativos de Médico, "Medicina de la vida" o "Remedio de las heridas" en sus himnos al nacimiento de Cristo. Como Clemente, el también alejandrino Evagrio Póntico se apoya en la figura del buen samaritano para dar a Cristo el título de Médico. Él cristianiza los tres pilares de la medicina hipocrática (enfermedad, enfermo y médico) ${ }^{14}$. El Médico divino cura todas nuestras dolencias o pasiones -vanagloria y orgullo, en particular- por medio de su Palabra, con los fármacos del amor y el "conocimiento sustancial". Retomando el tema origeniano de las denominaciones de Cristo, el título "Médico" es usado por Evagrio justamente en un sentido histórico salvífico y no simplemente metafórico (cf. Carta 24,1 a Melania).

Entre los Padres latinos anteriores a san Agustín el título de médico aplicado a Cristo aparece en san Jerónimo, en Nicetas de Remesiana y, sobre todo, en los escritos de san Ambrosio de Milán. Para Jerónimo, el “deus clinicus" de la mitología grecolatina (Esculapio) no cura las almas, sino que las pierde (Vita Hilarionis 21). En cambio, califica a Cristo de "spiritalis Hippocrates" cuya medicina alivia los males de nuestras almas (cf. Contra Ioan. Hier. 38). Según la Escritura, también los profetas son médicos espirituales, pero Cristo es el Sumo médico -“Archiater"-(cf. Com. In Malach.). En una de sus homilías, Nicetas de Remesiana enumera primero varios nombres bíblicos de Cristo, incluyendo el de médico, y ofrece después su proyección espiritual en cada situación concreta: “¿Estás enfermo y débil? Pídele remedio, pues es Médico" (De diversis appellationibus).

La obra del obispo de Milán ofrece una notable familiaridad con la terminología y las imágenes de la medicina de su tiempo, puestas al servicio de

${ }^{14}$ Cf. Comentario sobre Lucas (scholia I) citado por A, CASIDAY, Evagrius Ponticus, London 2006, p. 155. 
su misión pastoral ${ }^{15}$. Trata a menudo de la relación médico-paciente, de la confianza en el médico y de la voluntad de curación del enfermo. Se apoya en los textos del NT para subrayar que la acción curativa de Jesús se manifestaba en todo tiempo y lugar (cf. De virginitate 8,42). Inspirado en los autores griegos, alude a la figura de "Cristo Médico" en varias de sus obras. Según Ambrosio este título ejemplifica que "Lo tenemos todo en Cristo" $(\mathrm{Col} 3,11)^{16}$.

\section{CRISTO "MEDICUS HUMILIS"}

Como su maestro Ambrosio, también san Agustín emplea a menudo el título de "Christus Medicus" ${ }^{17}$. Cristo es "Señor y Médico nuestro" (ep. 219,2). Sin embargo, lo que le distingue del obispo de Milán es su original modo de usar el tema para subrayar la íntima relación de la humildad, como principal virtud de Cristo, con el misterio de la salvación. San Agustín no sólo llama a Cristo maestro o doctor de la humildad -"doctor humilitatis"- (en. Ps. 58,1,7) $)^{18}$; hay que considerar en particular la expresión "Medicus humilis" como genuinamente agustiniana.

La salud es un tema trasversal en la obra agustiniana y el título Christus Medicus aparece muchas veces en sus escritos, principalmente, en su predicación ${ }^{19}$. Abarca un amplio campo semántico: "Sanador", "Doctor”,

${ }^{15}$ Cf. R. Passarrella, "Conoscenze mediche ambrosiane ovvero la medicina nei Padri della Chiesa: questioni di método": Annali della Facoltà di Lettere e Filosofia dell'Università degli Studi di Milano 57 (2004) 70-91.

${ }^{16}$ De virginitate16,99: “Que toda alma se acerque a Él, ya sea que esté enferma a causa de los pecados cometidos con el cuerpo, o que esté clavada con los clavos de los deseos mundanos, o que todavía sea imperfecta, o que por medio de la atenta meditación sea ya proficiente, o incluso, aunque sea ya perfecta por sus muchas virtudes: toda alma está en las manos del Señor y Cristo lo es todo para nosotros. Si deseas curar tus heridas, Él es Médico".

17 Cf. R. Arbesmann, «The concept of Christus Medicus in Augustine»: Traditio 10 (1954) 1-28 (= www.jstor.org/stable/27830289); W. HARMLESS, «Christ the Pediatrician»: Augustinian Studies 28 (1997) 7-34; S. B. GRIFFITH, "Medical Imagery in the New Sermons of Augustine": Studia Patristica 43 (2003) 107-112; I. Bochet, «Medicina, medicus» en Augustinus Lexikon 3, Basel 2010, cols. 1230-1234.

18 Cf. V. H. Drecoll, «Der Christus humilis» en Id., Augustin Handbuch, Tübingen 2007, pp. 438-445.

${ }^{19}$ En los sermones se contabilizan unas doscientas menciones directas o indirectas. Hay nueve referencias explícitas al "Medicus humilis" (51,4; 159B,11; 159B,15; 198,32; 341A, 1 ; 360B, 17; 360B,24; 360B,26; 379,7). 
"Físico", "Cirujano", "Terapeuta”, etc. Como hemos visto, se trata de un tema muy apreciado de la antigüedad cristiana y uno de títulos más sugerentes de la soteriología agustiniana ${ }^{20}$. Refleja la curación y restauración que Agustín mismo experimentó, en el abrazo amoroso y los delicados cuidados de Cristo.

La expresión "Cristo médico" no es para san Agustín solamente un fecundo enunciado teológico inspirado en la Biblia y ya presente en la tradición patrística. Él la convierte en una profunda oración personal. Al comienzo del libro décimo de las Confesiones $(10,3,4)$, él invoca a Dios como "medice meus intime". Si la preocupación por la salud del cuerpo es tan importante para san Agustín, todavía presta una atención mayor por la salud interior del alma. "Dile a mi alma, yo soy tu salvación" (Sal 35,3; conf. 1,5,5). Él habla de la mano sanadora de Cristo médico: "He aquí que no oculto mis llagas. Tú eres el médico y yo estoy enfermo; Tú eres misericordioso, y yo miserable" (conf. 10,28,39). "No oculto mis llagas". Este es el primer paso hacia la curación: el propio reconocimiento de la necesidad de ser sanado.

Estamos ante un título cuyo uso por parte de san Agustín tuvo su origen en la polémica anti-maniquea, aunque va a aparecer en sus escritos, sobre todo, con motivo de la caída de Roma (410) y la controversia pelagiana. La figura del Médico humilde aparece tanto en relación con la encarnación, como con el misterio pascual de Cristo.

\subsection{La humildad de Cristo en la Carne}

El empleo tan frecuente del motivo de Cristo "Médico humilde"21 no se justificaría simplemente como una técnica catequética, que consistiría en la repetición de una idea para facilitar su asimilación. Más bien hay que buscar la explicación de la insistencia de san Agustín en dos razones de peso. Primero, como argumento ad hominem para refutar el abundante uso maniqueo de términos médicos en relación con la salvación y, sobre todo, en defensa de la presentación evangélica de Cristo como verdadero

${ }^{20}$ Cf. R. SAla, Médico y Liberador. Introducción a la soteriología de san Agustín, Madrid 2021, pp. 127-139.

${ }^{21}$ Cf. R. Arbesmann, «Christ the Medicus Humilis in St. Augustine» en Augustinus Magister II, Paris 1955, pp. 623-629. 
médico de los cuerpos y las almas, siguiendo la tradición contra el culto pagano. Y en segundo lugar, por el interés agustiniano en subrayar el valor redentor de la kénosis de Cristo, frente a la posición maniquea que negaba la realidad de la encarnación. Para san Agustín, la humanidad de Cristo es la verdadera medicina para la enfermedad del hombre, sobre todo para el orgullo (cf. agon. 11,12). A menudo él refiere la obra de la salvación en clave de salud:

Piensa primero en la salud. Ya que, aunque la enfermedad del alma es manifiesta, no quieren considerarla los hombres... Luego cualquier hombre que seas, ve que se te dice: "si no estás enfermo piensa en otras cosas; si la dolencia te declara que lo estás, piensa ante todo en tu salud". Tu salud es Cristo. Luego piensa en Cristo. Toma, pues, el cáliz de la salud, puesto que cura todas las enfermedades. Si quieres, obtendrás esta salud. Cuando intentas conseguir los honores y las riquezas, no las obtienes al instante de quererlas. Esto es cosa más excelente y sigue inmediatamente al querer: "El cura todas tus dolencias, El rescata tu vida de la destrucción". Toda tu enfermedad quedará curada cuando esto corruptible se vista de incorrupción (en. Ps. 102,6).

Por otra parte, frente a la doctrina pelagiana, san Agustín va a insistir en la absoluta necesidad del Médico divino para curar la enfermedad que padece todo el género humano, heredada como consecuencia del pecado de Adán. El poder sanador, la práctica y el programa de Cristo Médico es diseñado por Agustín en función de lo que él llama "dispensatio medicinalis", la economía salvífica de Dios (cf. Io. eu. tr. 36,4). Es el "programa de salud" de Dios para la humanidad, en el que Cristo es a la vez el médico, la medicina y la salud misma.

En la historia de la salvación, mediante sus asistentes, los profetas, Dios no solo curó algunas dolencias del enfermo -"más en esperanza que en realidad" (ep. Io. tr. 8,13) -, sino que previno de la grave evolución de la enfermedad y anunció la próxima venida del Médico (cf. s. 340a,5; 345.7; 346a,8). En efecto, como el paciente estaba tan mal, y no habiendo surtido efecto los medios de prevención por su culpa, Cristo médico se dignó venir hasta nosotros para devolvernos la salud. Para curar a un enfermo grave tuvo que venir un gran especialista: "Si vino del cielo el gran Médico es que un gran enfermo yacía en todo el orbe de la tierra. Ese enfermo es el género humano" (s. 175,1). La encarnación es la medicina de Dios para la 
humanidad. ¿Cuál era esa grave dolencia que aquejaba a la humanidad? Según san Agustín, el Médico celestial vino a curar la soberbia, "causa de todas las enfermedades" (Io. eu. tr. 25,16), raíz de todo pecado. La soberbia es también la peor enfermedad porque es la de quienes se resisten a reconocer su dolencia: "estaban enfermando y creían estar sanos" (s. 175,1). Cristo Médico cura la soberbia desobediente del hombre por medio de su obediencia humilde:

"La soberbia es el principio de todo pecado" [Sir 10,14-15]... Por este vicio, por este gran pecado de soberbia, vino Dios humilde. Esta es la causa de su venida, este el pecado grande, esta la enfermedad gravísima del alma que trajo del cielo al Médico omnipotente, que lo humilló hasta la forma de siervo [cf. Flp 2,7], que le afrentó, que le suspendió del madero, para que por lo saludable de tan eficaz medicina se curara este tumor (en. Ps. 18,2,15).

¿Por qué el "Médico omnipotente" elige la debilidad para convertirse también en "Médico humilde"? En la mentalidad de san Agustín para levantar a alguien caído es indispensable bajar al nivel en que se encuentra. Por eso Cristo se ha humillado, para hacerse como nosotros y así poder levantarnos. Lo explica así, comentando Jn 14,6 ("Yo soy el camino, la verdad y la vida. Nadie va al Padre sino por mí”). Como el enfermo estaba tan grave que no podía por sí mismo ir al médico, ha sido el médico quien ha llegado a su casa:

¿Cuál fue la causa de la humildad de Cristo, sino tu debilidad [infirmitas]? Tu debilidad te asediaba rigurosa y sin remedio, y eso hizo que viniese a ti un médico tan excelente. Porque si tu enfermedad fuese tal que, al menos, pudieras ir por ti mismo al médico, aun se podría decir que tu debilidad no era tan grave. Pero como tú no pudiste ir a Él, vino Él a ti. Y vino enseñándonos la humildad, por la cual retornemos, porque la soberbia no nos dejaba volver a la Vida. Más aun, había sido ella la que había hecho apartarse de la Vida el corazón humano que se había levantado contra Dios; despreciando, cuando estaba bien, los preceptos saludables, cayó el alma en la debilidad (s. 142,2 [Wilmart 11]. Cf. s. 88,7).

Para san Agustín el modelo paradigmático de Cristo Médico es el buen samaritano de la parábola lucana (cf. Lc 10,25-37). Él es la imagen del propio Cristo y de su obra sanadora: "Este samaritano es el mismo Señor que se apiadó del género humano... Compadeciéndose, se acercó, 
le curó, le condujo a la posada y cumplió con él la misericordia" (en. Ps. 30 II,1,8). Cristo, el buen samaritano, es el modelo de atención misericordiosa, el único que puede curar a quienes se hallan heridos en las cunetas de la vida (cf. en. Ps. 125,15).

Cristo es médico de los cuerpos y de las almas 22 (cf. s. 63a,2). San Agustín sitúa el camino hacia la curación en la obediencia del paciente a las prescripciones facultativas. Es el médico el que sabe lo que nos conviene para devolvernos la salud. El amor compasivo del médico por la persona enferma es lo que le lleva a luchar contra su enfermedad. Cristo médico no nos quiere enfermos, sino sanos (cf. s. 9,10;354,7). En esa trasformación consiste precisamente el aspecto sanante de la obra de la salvación.

La humildad es la condición esencial para recuperar la salud. Es el camino de la salvación. Y con tan decisiva intervención divina, ¿qué podemos concluir sobre el estado del paciente? San Agustín distingue dos tipos de enfermos: los que reconocen su enfermedad y los que no. Cristo viene a sanar a todos, pero la curación de los últimos, que "por la fiebre perdieron la cabeza” (s. 175,2), ha sido mucho más onerosa.

Cristo vino a los enfermos. Los halló a todos enfermos. Que nadie alardee de su salud, no sea que el Médico lo abandone. Los encontró a todos enfermos. La afirmación es del apóstol: "En efecto, todos pecaron y están privados de la gloria de Dios" (Rm 3,23). Halló a todos enfermos pero eran dos las clases de enfermos. Unos se acercaban al médico, se adherían a Cristo, le escuchaban, le honraban, le seguían y se convertían. El recibía a todos, sin repugnancia, para sanarlos, porque los sanaba gratuitamente, los sanaba con su omnipotencia... En cambio, el otro género de enfermos, que habían perdido ya la razón a causa de la enfermedad e ignoraban que estaban enfermos, le insultaban porque recibía a los enfermos... "No necesitan de médico los sanos sino los enfermos". Y les manifestó quienes eran los sanos y quiénes los enfermos. "no vine -dijoa llamar a los justos, sino a los pecadores" [Mt 9,11-13]. "Si los pecadores

22 "El bien que dice relación al cuerpo lleva el nombre genérico de medicina, y lo que hace bien al alma, de instrucción o disciplina. Medicina llamo yo todo lo que sirve para conservar la salud del cuerpo, para repararla... Y lo mismo que se dice ser don del cielo las medicinas del alma, se debe decir también de las del cuerpo; pues si nos remontamos al origen de las cosas, solo pueden venir de Dios, que es la razón de la estabilidad y la conservación de todas las cosas" (mor. I,27,52 y 28,55). 
no se acercan a mí” -dijo- “¿para qué he venido? ¿Quiénes fueron la causa de mi venida?" Si todos están sanos, ¿por qué bajó del cielo tan gran médico? ¿por qué nos preparó una medicina de su sangre y no de su alacena? Por tanto, el grupo de enfermos con dolencias más leves, pero que eran conscientes de ellas, se adherían al médico para curarse. En cambio, los más graves insultaban al médico y calumniaban a los enfermos. ¿A qué extremo llegó su delirio? Hasta detener, esposar, flagelar, coronar de espinas, colgar de la cruz y dar muerte en ella al mismo médico. ¿De qué te admiras? El enfermo dio muerte al médico, pero el mismo médico, muerto, devolvió la salud al trastornado (s. 80,4).

\subsection{La humillación del Crucificado}

En la obra redentora, Cristo médico no solo ha venido a nuestra propia casa a traernos la curación personalmente, sino que se ha convertido también Él mismo en medicina, entregando la vida por nuestra salud. De su sangre ha hecho la medicina que cura (cf. s. 174,6; 175,2-3). Es más, Él mismo tomó primero la poción amarga para dar ejemplo al enfermo:

He aquí que llevo tu enfermedad: bebe el cáliz amargo. Tú hiciste que te fuesen tan fatigosos aquellos preceptos míos, que se te dieron llenos de dulzura cuando estabas sano. Los despreciaste y comenzaste a fatigarte; no puedes sanar si no bebes el cáliz amargo, el cáliz de las tentaciones en que abunda esta vida, el cáliz de las tribulaciones, de las angustias, de los sufrimientos. "Bebe", dice, "bebe para vivir". Y para que el enfermo no le respondiera: "no puedo, no lo soporto, no lo bebo", lo bebió antes el médico sano, para que no dudare en beberlo el enfermo. ¿Qué hay de amargo en tal bebida que no la bebiera él?... Si son amargos los dolores, él fue atado, flagelado y crucificado. Si es amarga la muerte, también murió. Si la debilidad aborrece cierto género de muerte, nada había en aquel tiempo más ignominioso que la muerte de cruz (s. 88,7).

Hay en este texto una alusión implícita al relato evangélico de la plegaria de Jesús en el huerto de los olivos. Narrada por los Sinópticos (cf. Mc 14,36 par.), pone de relieve la verdadera humanidad del Salvador, "probado en todo como nosotros, excepto en el pecado" (Hb 4,15). Comentando el Salmo 115 san Agustín escruta el significado del "cáliz de la salvación": "el cáliz de la pasión, amargo y saludable; cáliz que si no lo hubiera bebido primero el médico, hubiera temido hasta tocarlo el enfermo" (s. 329,2). 
En los Tratados sobre el Evangelio de san Juan, ilustrando la impotencia del hombre ante la ley, san Agustín exhorta a confesar la propia enfermedad e invoca la acción del médico. Cristo es el médico que vence todos nuestros males y nos devuelve la salud. Justamente Aquel torturado y crucificado se ha convertido en el "médico total" (medicus totus) que cura nuestras llagas. Solo Él cura nuestras heridas mortales:

¿Qué médico es ése? Nuestro Señor Jesucristo. Y ¿quién es Nuestro Señor Jesucristo? El mismo que vieron los ojos de quienes le crucificaron, y que fue arrestado, abofeteado, azotado, cubierto de esputos, coronado de espinas, clavado en la cruz, muerto, abierto por la lanza, bajado de la cruz y puesto en el sepulcro. Ése es sin duda nuestro Señor Jesucristo; Él mismo en persona, él es el médico único de nuestras llagas. Es ese mismo que clavado en la cruz y pendiente de ella fue insultado y escarnecido por sus perseguidores, que meneando la cabeza, decían: "Si eres Hijo de Dios, y baja de la cruz” [Mt 27,39-40]; Él es el médico total, justamente Él... Curó tus llagas allí mismo, donde soportó por tanto tiempo las suyas; allí te curó de la muerte eterna, donde él se dignó morir temporalmente. ¿Murió Él o, más bien, con Él murió la muerte? ¿Qué muerte es esta que da muerte a la muerte misma? (Io. eu. tr. 3,3).

San Agustín habla de "la muerte que mata la muerte". Esta paradoja no es una licencia retórica, sino que expresa el significado último de la obra de la redención. Sobre todo colgado en la cruz, Jesucristo se nos muestra como el médico misericordioso que nos salva cargando sobre sí mismo el peso de todas nuestras enfermedades:

A pesar de que sus miembros colgaban del madero; a pesar de que sus manos y pies estaban fijados con clavos; a pesar de que aquellos [sus adversarios] seguían mostrando su crueldad con la lengua, a pesar de que, tras haber derramado su sangre, no estaban aun satisfechos; a pesar de que, enfermos, no reconocían al médico, dijo: "Padre, perdónalos porque no saben lo que hacen" [Lc 23,34], como si dijera: "Yo vine a curar a los enfermos; el hecho de que no me reconozcan se debe a la excesiva fiebre". Porque es manso y humilde de corazón dice:"Padre, perdónales porque no saben lo que hacen" [Lc 23,34] (s. 279,3; cf. 284,6).

La revelación de la infinita misericordia de Dios en la cruz de Jesús es un aspecto fundamental para poder reconocer el alcance universal de la obra de la redención. Nadie queda excluido. El obispo de Hipona su- 
braya con insistencia que para este médico no hay ninguna enfermedad incurable (cf. s. 335c,10), ningún pecado imperdonable:

Cristo ama a los pecadores como el médico al enfermo: con vistas a eliminar la fiebre y sanarlo. No es su deseo que esté siempre enfermo, para tener siempre a quién visitar; lo que quiere es sanarlo. Por tanto, el Señor no vino a llamar a los justos sino a los pecadores [cf. Mt 9,13], para justificar al impío. De un idólatra hizo un fiel, de un borracho un sobrio, de un lujurioso un parco; a un avaro lo convirtió en generoso. [...] Cree, por tanto, y camina en la fe: tu salvación está en la esperanza. Ha comenzado ya a curarte el mejor médico, aquel para quien no hay enfermedad incurable. No temas los pecados que quizás cometiste en el pasado, por graves e increíbles que sean; la enfermedad es grande, pero es mayor el médico. No te preocupes de lo pasado; se anulará todo, absolutamente todo, en el sacramento [del bautismo] (s. 97a,1-2).

La aplicación de la medicina a menudo causa dolor y no se ven inmediatamente sus efectos. Pero en ningún caso se trata de un castigo. Debemos confiar en el Médico. Su medicina actúa al contrario que nuestro pecado: en principio nos provoca cierto malestar, pero conduce a la curación final ${ }^{23}$. Por otra parte, san Agustín señala que la ausencia de dolor es un síntoma ambiguo. "Hay que distinguir la ausencia de dolor debida a la salud de la debida a la insensibilidad". Puede significar que el remedio está produciendo efectos positivos en la salud del enfermo, pero también que la enfermedad ha ocasionado la pérdida de sensibilidad en el paciente, lo cual indica que está todavía más grave o, incluso, que ya ha fallecido: "vean, pues estos, que no sienten dolor ni temor, si en vez de estar sanos no están muertos" (s. 348,3).

En resumen, como el ser humano está gravemente enfermo a causa del pecado, Cristo ha venido a curarlo. Él es el Médico divino que, tomando la condición humana, conoce bien nuestra enfermedad, la diagnostica y además administra la medicina adecuada para curarla. Esa no es otra que la humildad. Para que el enfermo no rechace el tratamiento, el mismo Médico ha probado antes su eficacia. Humillado hasta la muerte

23 "El mal te deleitaba cuando lo cometiste, pero al cometerlo fuiste a dar en la enfermedad. La medicina actúa al contrario: te procura un dolor temporal para que alcances la salud duradera. Sírvete de ella y no la rechaces” (s. 278,5). 
y muerte de cruz, Cristo es a la vez Médico que entrega la vida y medicina que nos salva.

\section{LA MEDICINA DE LA GRACIA}

Médico mío íntimo, hazme ver claro con qué fruto hago yo esto. Porque las confesiones de mis males pretéritos -que Tú perdonaste ya y cubriste, para hacerme feliz en ti [cf. Sal 31,1]...-, cuando son leídas y oídas, excitan el corazón para que no se duerma en la desesperación y diga: "no puedo", sino que le despierte al amor de tu misericordia y a la dulzura de tu gracia, por la que es poderoso todo débil [cf. 2Cor 12,10] que se da cuenta por ella [por la gracia] de su debilidad (conf. 10,3,4).

En la polémica pelagiana san Agustín va a subrayar de un modo especial el aspecto curativo de la gracia. La llama "medicina del Salvador" (nat. et gr. 54,64). Entre otras clasificaciones ${ }^{24}$, el léxico agustiniano de la gracia se refiere a la gracia medicinal o sanante. Según él, este "auxilio medicinal" no solo perdona los pecados cometidos -como admitía también Pelagio- sino que ayuda para evitar los futuros (cf. nat. et gr. 34,39). Él presenta la gracia como fármaco necesario y gratuito que cura nuestros males.

\subsection{UNA MEDICINA NECESARIA}

San Agustín defiende la existencia de una "gracia que nos permite dominar las concupiscencias y tentaciones" y que por tanto "no es la naturaleza, sino que por ella es sanada y socorrida la naturaleza" (ep. 177,4.7). Frente a Pelagio distingue entre naturaleza y gracia de Cristo; entre gracia de creación y gracia de justificación. Esta última es una "gracia mayor" que la común gracia de creación (cf. s. 26,12). El presupuesto fundamental del pensamiento del "doctor de la gracia" en la polémica antipelagiana es su firme oposición a la pretensión de construir un cristianismo sin Cristo. Es decir, su convicción de la imposibilidad de una vida cristiana en la que la persona pudiera salvarse al margen de la obra redentora de Cristo. San Agustín considera que la doctrina pelagiana es la negación de la enseñanza paulina y joánica en este sentido. Él entra inicialmente en la polémica en el 412 con su obra Consecuencias y perdón de los pecados (y el bautismo

${ }^{24}$ Cf. F. Moriones, Teología de san Agustín, Madrid 2004, pp. 270-272. 
de los niños a Marcelino), dirigida contra Celestio, mostrando la falsedad de la oposición entre gracia y libertad. Pero su confrontación directa con Pelagio solo se inaugura poco después con La naturaleza y la gracia (415), escrito de réplica al De natura de aquel.

En sus obras san Agustín se opone a la doctrina pelagiana por varias razones. Primero, porque supone el rechazo radical de la condición pecadora del ser humano (nacido de Adán) frente a Dios, que él mismo ha descrito en conf. 10,28,39. Como dice sabiamente en el s. 156,2 "quien niega estar enfermo, considera superfluo al Salvador" y nos bastamos a nosotros mismos para arruinar nuestra salud, pero para curarnos es necesaria la ayuda del médico. En segundo lugar, porque Pelagio niega la primacía absoluta de la gracia sobre nuestras obras. San Agustín ilumina la "ceguera" pelagiana con la imagen de la visión: del mismo modo que el ojo, aunque esté sano, no puede ver sin luz; el hombre, aunque esté espiritualmente sano, tampoco puede vivir bien sin la gracia (cf. nat. et gr. 27,30). Utiliza, además, otros dos buenos ejemplos para explicarlo: el fuego y la rueda ${ }^{25}$. Y sobre todo, en tercer lugar, porque -subraya san Agustín- la doctrina de Pelagio significa la negación de la cruz de $\mathrm{Cristo}^{26}$. Si Pelagio tiene razón, no tenemos necesidad de ser salvados: somos perfectamente capaces de conseguir la salvación por nosotros mismos. San Agustín invoca con frecuencia el argumento soteriológico -"quod non assumptum, non sanatum"- (cf. ciu. 11,2; s. 237,4), tan recurrente entre los Padres de la Iglesia.

El pastor de Hipona concibe la gracia como luz y amor. Son las medicinas que curan, respectivamente, las dos heridas del pecado original -“los vicios que paralizan la voluntad para hacer una obra buena o abstenerse de una mala"-: la ignorancia (ignorantia) y la concupiscencia (cupiditas). "Que se nos dé a conocer lo que se hallaba oculto y nos aficionemos a lo que antes no nos atraía, obra es de la gracia de Dios" (pecc. mer. 2,17,26). Identificadas las enfermedades, san Agustín les aplica el remedio oportuno.

${ }^{25}$ Simpl. 1,2,3: "Las buenas obras siguen al que recibe la gracia; no producen ellas la gracia, antes bien, son fruto de la gracia. Pues no calienta el fuego para arder, sino porque arde; ni la rueda corre bien para que sea redonda, sino porque es redonda; de igual modo nadie obra el bien para recibir la gracia, sino por haberla recibido".

26 "Si no hubiese muerto por nuestros delitos y resucitado por nuestra justificación.., ¿acaso les faltaría a los hombres esa posibilidad de la naturaleza que Pelagio defiende?" (ep. 177,9). 
La luz cura las tinieblas de la ignorancia iluminando el entendimiento con la claridad de la verdad. El amor cura los ardores de la concupiscencia inspirando y fortaleciendo la voluntad. Ambos fármacos son necesarios. La doctrina pelagiana admitía la función iluminativa de la gracia, sin embargo desconocía su función caritativa, es decir, la "inspiratio dilectionis" que requiere la voluntad humana para obrar el bien. "Pues no se sigue que el que tiene el don de ciencia, por medio del cual conoce lo que debe hacer, tenga también el de la caridad para ejecutarlo" (gr. pecc. or. I,33,36).

Con un juego de palabras san Agustín sostiene que no basta con conocer la ley porque "iubet sed non iuvat", ni conocer el evangelio que descubre la llaga, pero no la cura; es precisa la gracia para obrar con amor lo que sabemos que hay que hacer (ep. 177,5; cf. gr. et pecc. or I,9,10). La gracia "natural" que defendía Pelagio no procura la curación. El ser humano no solo está enfermo de ignorancia, también de concupiscencia. Inclinado hacia el mal, el conocimiento del bien que manda la ley es totalmente insuficiente; es preciso amar el bien: "Y aun cuando lo que debe obrar el hombre y el fin último de la obra estuviere patente, aun así no se obra, no se abraza el bien, ni se vive justamente, si al mismo tiempo el bien no nos deleita y no se ama" (spirit. et litt. 3,5).

\subsection{UNA MEDICINA GRATUITA}

El Médico humilde cura gratuitamente con su omnipotencia (cf. $s$. $80,4 ; 156,2)$. En numerosos textos subraya san Agustín el carácter gratuito del don de la gracia (cf. Io. eu. tr. 86,2; nat. et gr. 4,4; en. Ps. 18,2,2; retr. I,23,2...). Dice él en el Sermón 169: "Gratuitamente habéis sido salvados por medio de la fe, y esto no procede de vosotros sino que es un don de Dios". La dispensación de la gracia no está nunca en función de las obras fruto de la libertad humana. Es justamente al revés: "La gracia precedió a tus merecimientos. No procede la gracia del mérito, sino el mérito de la gracia. Pues si la gracia procede del mérito, la compraste, no la recibiste gratuitamente". La salvación es un don gratuito: "das completamente gratis, gratuitamente salvas Tú, que nada encuentras que merezca la salvación..." (s. 169,3).

“QQué tienes que no hayas recibido?” (1Cor 4,7). Predicando sobre el episodio evangélico de la curación de los diez leprosos (cf. Lc 17,11-19) el obispo de Hipona dice que nada es nuestro, salvo el pecado, e invita a 
quienes han sido curados de su enfermedad a elevar el corazón [sursum corda] y a dar gracias a Dios (s. 176,6). Él aduce muchos otros pasajes bíblicos en apoyo de la gratuidad de la gracia (cf. Ez 27; 36,22; Prov 8 LXX; Jn 3,8; Jn 15,5; 1Jn 4,7; Rm 8,2-6; Rm 12,3;2Cor 3,5; Flp 2,13, etc.). Recurre también al significado del propio término "gracia" como argumento: “¿Qué es la gracia? Un don gratuito -gratis data-. ¿Qué es un don gratuito? Una simple donación, no una retribución. Si se debiera como recompensa, no sería gracia" (Io. eu. tr. 3,9) ${ }^{27}$.

Para san Agustín el dato primero es la gracia. Siempre es Dios mismo quien toma la iniciativa ante al hombre. Dentro del diseño universal de la historia de la salvación esto se verifica en la obra de la creación, en el don de la primera alianza y en el don definitivo de la encarnación redentora. El Creador busca al ser humano, llamándolo a la existencia. Después del pecado, lo vuelve a buscar y llamar: “Adán, ¿dónde estás?” (Gn 3,9). Ese primer paso posibilita la respuesta humana. Del mismo modo, fue la gracia divina la que llenó a María y permitió su libre fiat (cf. Lc 1,28-38). "La encarnación -escribe san Agustín- es la manifestación suprema de la gracia" (ciu. 10,29,1).

¿Cómo comprender entonces la relación entre gracia y libertad desde la perspectiva agustiniana? Es preciso asumir que se trata de factores que pertenecen a distintos órdenes de la realidad. La gracia hay que situarla en el orden divino; mientras que la libertad tiene su propio espacio en la esfera de lo humano. Dado que la acción de Dios y la del hombre no están en el mismo plano, no pueden competir entre sí. San Agustín piensa que el mejor camino para comprender la relación entre ambas es la analogía con la creación. El ser de las criaturas depende totalmente de su Creador, sin cuya voluntad creadora dejarían de ser. En cambio, en cuanto distinta de Dios, la criatura dispone de una autonomía de acción.

Dios me creó con el libre albedrío; si pequé, pequé yo, de modo que no solo confesaré mi iniquidad al Señor, sino que, además, la confesaré contra mí, no contra Él. "Yo dije: Señor, ten piedad de mî" [Sal 40,5]. Clama el enfermo al médico. "Yo dije". ¿Por qué dice "yo dije"? Bastaba haber dicho "dije". Si dijo "yo" con énfasis: yo, yo, no el destino, ni la fortuna, ni el diablo" (en. Ps. 31,2,16).

${ }^{27}$ Cf. en. Ps. 70,2,1; gr. pecc. or. I,23,24. 
Lo mismo ocurre con la gracia: ella crea y posibilita nuestra libertad espiritual. Su finalidad es posibilitar un interlocutor verdaderamente libre ante Dios. Por eso, el asentimiento a la gracia es un verdadero acto de libertad humana, aunque por su origen no deja de ser siempre una gracia "de Dios". San Agustín emplea también un razonamiento directamente soteriológico para preservar a la vez la gracia y la libertad. Presenta a Cristo como Salvador y como Juez: "Si no existe la gracia de Dios, ¿cómo salva al mundo? Y si no existe el libre albedrío, ¿cómo juzga al mundo?" (ep. 214.2).

En la relación entre la gracia de Dios y la libertad humana se dirime nuestra adopción filial y nuestra salvación. Para el ser humano acceder a la libertad es aceptarse a sí mismo y su propia vocación, es aceptar responder al don recibido. Antes que ser sujeto del deseo de Dios, él es objeto de ese deseo. Para san Agustín, este dato fundamental no es una consecuencia del pecado; es consecuencia de nuestra condición de criaturas. La tentación de querer convertirse él mismo en su propio dios (cf. Gn 3,5), sin referencia a una alteridad, pende siempre sobre el ser humano como una espada de Damocles.

Por último, para san Agustín, en el caso del hombre pecador, la liberación de su libertad por la gracia acontece paulatinamente en un proceso de conversión. La libertad devuelta a sí misma sigue estando dividida. Poco a poco, la gracia que empuja a amar y a servir a Dios y a los demás, a la ascesis y a las buenas obras, nos lleva a recuperar la unidad y el equilibrio personal. La doctrina agustiniana de la gracia, siguiendo fielmente a san Pablo, justifica nuestra libertad. En este campo, el pensamiento de san Agustín inspirará la teología latina desde la Edad Media, particularmente a través de la obra de santo Tomás de Aquino, que le dará una forma sistemática. Y se va a convertir en la interpretación eclesial de la relación entre gracia y libertad, sancionada oficialmente por el magisterio en el Concilio de Trento (1547) en el Decreto sobre la justificación (DH 1520-1583).

\section{CONCLUSIONES}

Con el lema "Ser humano salva vidas", a principios del año 2014, "Médicos sin fronteras" lanzó una nueva campaña promocional para captar socios. Su cartel publicitario mostraba la fotografía en blanco y negro 
de un joven médico -Manu-, voluntario en Sudán del Sur, aplicando su estetoscopio a un bebé africano. Junto al lema de la campaña, en los países de habla hispana la imagen llevaba superpuesto el siguiente texto: "Lo único capaz de salvar a un ser humano es otro ser humano". Sin duda, era un mensaje impactante que da que pensar, especialmente hoy en estos tiempos de pandemias a escala planetaria. Hay que reconocer que, en un primer momento, una percepción aparentemente tan secularizada de la salvación puede resultar decepcionante. Ahora bien, si somos capaces de descubrir el rostro encarnado de Cristo -el Hijo de Dios hecho hombreen el de Manu, el médico, entonces tenemos un verdadero icono de la salvación cristiana.

De la interpretación agustiniana de la imagen de Cristo Médico se desprenden dos valiosas verdades de fe que parece oportuno redescubrir en nuestros días. En primer lugar, la necesidad de ser salvados. La Congregación para la Doctrina de la fe en la Carta Placuit Deo (2018) advertía sobre dos tendencias actuales distorsionadoras de la concepción cristiana de la salvación. Por un lado, el neo-pelagianismo que presenta a un ser humano radicalmente autónomo capaz de salvarse a sí mismo por sus propios medios, desconociendo su dependencia de Dios y de los demás. Por otro, el neo-gnosticismo que pretende una salvación puramente interior, consistente en acceder por la sola razón a la unión con Dios, despreciando las relaciones con los demás y con el mundo. Ambas visiones no solo actualizan esas antiguas herejías de los orígenes del cristianismo, a las que replicó san Agustín con sus escritos, sino que, en último término, reeditan las perennes tentaciones del fariseísmo legalista y del espiritualismo desencarnado. Tras épocas de entusiasmo antropológico, más o menos justificado, las circunstancias actuales nos alertan frente a los sueños de autorredención, que pueden seducir inicialmente, pero que, al final, acaban condenando inexorablemente a una existencia personal y comunitaria "autorreferencial y prometeica" (Evangelii Gaudium 94) al margen de Dios.

Además, en segundo lugar, para san Agustín Cristo no solo nos trae la salvación, sino que la salvación de Dios es Cristo Jesús (cf. en. Ps. 49,31). Según él, tanto el Médico como la "medicina de Dios" para nuestra salud no es ningún héroe sobrehumano ni ningún ángel de la guarda, sino solo la persona de Jesucristo. De la mano de la Escritura y de la fe de la Iglesia, san Agustín nos enseña que únicamente en el "Médico humilde" podemos recibir la salvación. En efecto, la "humildad" de Cristo es el símbolo de su en- 
carnación salvífica; la "enfermedad" del hombre, el símbolo del pecado y, más precisamente, de su raíz, la soberbia. Según el pastor de Hipona con ella se introduce el contagioso pecado de Adán y la obra redentora debía curarla con la medicina de la humildad del Nuevo Adán. La finalidad de la redención es la sanación definitiva de esa "pandemia" crónica de la humanidad. Por Cristo y en Cristo, que con su muerte venció a la muerte y con su resurrección nos dio la vida, se ilumina el enigma del dolor y de la muerte (cf. GS 22). Solo Él es el médico que nos da la salud eterna (cf. s. 88,1). 